\title{
Do alternating-color words facilitate reading aloud text in Chinese? Evidence with developing and adult readers
}

\author{
Manuel Perea $^{1,2} \cdot$ Xiaoyun Wang $^{3}$
}

Published online: 12 June 2017

(C) Psychonomic Society, Inc. 2017

\begin{abstract}
Prior research has shown that colors induce perceptual grouping and, hence, colors can be used as word dividers during reading (Pinna \& Deiana, 2014). This issue is particularly important for those writing systems that do not employ interword spaces (e.g., Chinese). The rationale is that alternating colors across words in these scripts may facilitate the process of word identification without altering the spatial distribution of text. Here, we tested whether color alternation across words produces a benefit in a reading-aloud task in native speakers of Chinese. Participants had to read two texts: one with color alternation across words and the other with monocolor words. Experiments 1 and 2 were conducted with adult readers, whereas Experiment 3 was conducted with developing readers (Grade 2 children). Results showed that color information facilitated reading aloud a text for adult readersrestricted to texts containing technical, unfamiliar words (Experiment 2)-and developing readers. We examined the implications of these findings in the context of literacy and vocabulary training.
\end{abstract}

Keywords Word recognition · Literacy training · Reading · Color information

To delimit where each word begins and ends in a text, most writing systems employ interword spaces. Unsurprisingly, the

Manuel Perea

mperea@uv.es

1 Departamento de Metodología, Universitat de València, Av. Blasco Ibáñez, 21, 46010 Valencia, Spain

2 Basque Center on Brain, Cognition, and Language, Donostia, Spain

3 Zhejiang Gongshang University, Hangzhou, China removal of interword spaces in Western languages (e.g., apoetcansurviveeverythingbutamisprint) has a large reading cost relative to the spaced format (e.g., see Pollatsek \& Rayner, 1982; Rayner, Fischer, \& Pollatsek, 1998). Importantly, Chinese and other writing systems (Japanese, Thai, among others) do not employ interword spaces (e.g., 大象打算在森林开一家商店 in Chinese [The elephant plans to open a shop in the forest]), and skilled readers can read the resulting text without apparent difficulty — note that around $72 \%$ of Chinese words are formed by two characters, but words composed of one, three, and four characters are also common $(6 \%, 12 \%$, and $10 \%$, respectively; see Li, Bicknell, Liu, Wei, \& Rayner, 2014).

Inserting interword spaces in unspaced scripts does not typically produce faster reading times than the standard unspaced format (e.g., see Bai, Yan, Liversedge, Zang, \& Rayner, 2008; Sainio, Hyönä, Bingushi, \& Bertram, 2007; Winskel, Radach, \& Luksaneeyanawin, 2009, for evidence in Chinese, Japanese Kanji, and Thai, respectively). As argued by Bai et al. (2008), this outcome can be the net result of two opposing effects. On the one hand, word-spaced text may facilitate the process of word identification (i.e., the inclusion of spaces between words helps delineate word boundaries and it may also reduce lateral inhibition), but, on the other hand, spaced text is visually unfamiliar. Evidence supporting this interpretation comes from an eye-tracking experiment conducted by Zang, Liang, Bai, Yan, and Liversedge (2013) in Chinese. Zang et al. (2013) found briefer first-pass fixation durations on words in spaced than in unspaced sentences with adults and children - this would be consistent with the idea that word identification is facilitated by the presence of interword spaces. However, the advantage of the sentences with interword spaces vanished in the total reading times, which is consistent with the idea of a cost due to the visual unfamiliarity of the stimuli. 
What we should also note here is that inserting interword spaces in unspaced scripts such as Chinese has a beneficial effect under some circumstances (e.g., when reading unfamiliar words). Blythe et al. (2012) found that native speakers of Chinese (both children and adults) benefitted from the presence of interword spaces around a target stimulus when learning new words. Likewise, Shen et al. (2012) found that inserting interword spaces had a beneficial effect on nonnative readers that were learning Chinese relative to the standard unspaced format. This was so for both nonnative readers from another unspaced script (e.g., Japanese, Thai) and nonnative readers from spaced scripts (e.g., Korean, English; see also Bai et al., 2013, for similar evidence with native English speakers learning Chinese).

Thus, inserting interword spaces to delineate word boundaries may help word learning and word identification in unspaced scripts, which has important implications for reading instruction methods (see Shen et al., 2012). However, an unintended consequence of this manipulation is that it necessarily alters the spatial distribution of the sentences (e.g., the sentence大象打算在森林开一家商店 would be presented as 大 象 打算在 森林开一家商店; see also Häikiö, Hyönä, \& Bertram, 2015, for a similar observation regarding the insertion of hyphens in Finnish books for beginning readers).

In the present series of experiments, we examine the efficiency of other, less intrusive, visual cues that delimit word boundaries without modifying the spatial distribution of text. One such option is the use of bold emphasis across alternate words, as in the sentence this sentenceiseasytoread. Perea and Acha (2009) found that alternating-bold sentences in Spanish produced faster reading times than did unspaced sentences. However, they also found a large reading cost of alternating-bold sentences relative to the standard-spaced sentences (see also Leyland, Kirkby, Juhasz, Pollatsek, \& Liversedge, 2013, for a similar manipulation using shading as a visual cue). Here, we examined the role of a more powerful visual cue (i.e., the use of alternating-color words) in an unspaced writing system (Chinese) by comparing reading aloud times in mono-color versus multicolor text (e.g., 大象打算在森林开一家商店 vs. 大象打算在森 林开一家商店 [The elephant /plans to/ in / the forest / open / a / shop]).

The rationale behind the present experiments is that color information may induce "visual grouping and wholeness" (Pinna \& Deiana, 2014, p. 319; see also Goldfarb \& Treisman, 2011; Häikiö et al., 2015; Livingstone \& Hubel, 1988; Perea, Tejero, \& Winskel, 2015; Pinna, Uccula, \& Tanca, 2010; Treisman \& Gelade, 1980). If the unit of processing is the word, and color demarcation operates at that level of granularity, then it should produce a facilitative effect during reading. Indeed, a number of recent experiments in spaced orthographies with skilled adult readers have shown that color information helps delineate word boundaries during reading (e.g., Perea et al., 2015; Pinna \& Deiana, 2014; see also Häikiö et al., 2015, for a similar manipulation at the syllable level). Specifically, Pinna and Deiana (2014) compared reading speed, reading easiness (as rated by readers on a scale from 0 to 100), and comprehension scores in a readingaloud task in Italian using unspaced mono-color text and alternating-color text (e.g., tobeornottobe vs. tobeornottobe, respectively). Pinna and Deiana found faster reading times and increased reading easiness for the alternating-color unspaced text over the mono-color unspaced text; on the other hand, there were no differences in comprehension scores. In another experiment, Pinna and Deiana (2014) found higher values in reading easiness for alternating-color text than for mono-color text in the presence of interword spaces (e.g., to be or not to be vs. to be or not to be; see also Pinna et al., 2010, for converging evidence using a reading-aloud task). Pinna and Deiana concluded: "The results demonstrated that the chromatic similarity can influence the process of segmentation of words and, therefore, the phenomenal grouping and shape formation" (p. 348). Likewise, Perea et al. (2015) examined the role of color information in a sentence-reading experiment in which participants silently read three types of sentences in Spanish while their eye movements were registered: (1) unspaced sentences in which each alternate word was displayed in different color (e.g., tobeornottobe); (2) spaced sentences in which each alternate word was displayed in different color (e.g., to be or not to be); and (3) unspaced monocolor sentences (e.g., tobeornottobe). Perea et al. found a small reading cost in the unspaced, alternating-color sentences relative to the spaced sentences (around 5\% of the total reading time), whereas the unspaced mono-color sentences produced a dramatically larger reading cost (around $31 \%$ of the total reading time; see also Reingold, Sheridan, Meadmore, Drieghe, \& Liversedge, 2016, for the use of color as a selective cue during sentence reading). While color information appears to be a powerful visual cue to segment words, Perea et al. (2015) pondered, "An important question for further research is whether children's reading benefits from the use of unspaced sentences with alternating colour words (e.g., when learning unspaced languages: Chinese, Thai)" (p. 13). The present study aims to provide an answer to this question.

The main goal of the present experiments is to examine whether adult and developing readers of an unspaced writing system (Chinese) can benefit from the use of color information regarding word boundaries when reading aloud a text. Specifically, in the present experiments, we compared the reading times of multicolor texts (e.g., 大象打算在森林开一家商店) and standard mono-color texts (e.g., 大象打算在森林开一家商店－comprehension scores were also obtained for each text. As shown by Blythe et al. (2012) and Shen et al. (2012), there is a facilitative effect of demarcation in Chinese during silent sentence reading when measuring on-line eye-movement data-via inserting interword spaces. Here, we examined whether alternating-color words (i.e., a visual cue that 
does not alter the spatial distribution of text) facilitate reading aloud in Chinese. It is important to stress here that, for developing readers (Grade 2 children), reading aloud may be more prevalent than silent reading. For each experiment, we compiled two texts of similar length and difficulty for participants to read aloud. One of the texts was presented in a multicolored format (i.e., using an alternating-color manipulation), and the other text was presented in a mono-colored format. The order/condition of the texts was fully counterbalanced. We employed four colors rather than two colors to avoid potential perceptual grouping between the $n-1$ word and the $n+1$ word (see also Pinna \& Deiana, 2014, for a similar procedure). To segment the words for the multicolor texts, we followed the guidelines from the Contemporary Chinese Language Word Segmentation Specification for Information Processing (State Administration of Quality Supervision, and Standardization Administration of China, 1993). As word segmentation among Chinese readers may not necessarily follow all these recommendations (see $\mathrm{Liu}, \mathrm{Li}, \mathrm{Lin}, \& \mathrm{Li}, 2013$ ), we verified that their agreement on word segmentation was at ceiling level (see Method sections).

Experiments 1 and 2 were conducted with adult skilled readers, whereas Experiment 3 was conducted with developing readers (Grade 2 children). The difference between Experiments 1 and 2 was the difficulty of the texts (the difficulty ratings in a 1 to 7 Likert scale, where $1=$ very easy and 7 = very difficult, were 2.0-2.2 in Experiment 1 and 5.8-5.9 in Experiment 2). The rationale behind this manipulation is that texts that include technical, relatively unfamiliar words may induce more reliance on word segmentation cues such as color alternation than standard easy-to-read texts (see Blythe et al., 2012, for evidence using interword spacing as visual cues when learning new words). Finally, the materials in Experiment 3 were adapted to the reading proficiency of Grade 2 children.

As indicated earlier, there is some evidence showing that, when measuring total reading times in relatively easy-toread texts, adult readers of unspaced writing systems do not obtain much benefit from the use of visual cues such as interword spaces to delimitate word boundaries. For instance, Bai et al. (2008) failed to find differences in total reading times between unspaced and spaced sentences in Chinese with adult readers (see also Sainio et al., 2007, for similar evidence in Japanese Kanji, and Winskel et al., 2009, for similar evidence in Thai). Bai et al. (2008) also conducted an experiment in which each alternating word in Chinese was highlighted (e.g., as in 大象打算在森林开一家商店) and failed to find any differences in the total reading times between highlighted and standard sentences. More related to the present study, Perea et al. (2015) conducted a sentence reading experiment with adult skilled readers of Thai in which each alternating word was in different color (green/ red) or in the same color (either green or red). They found no differences in reading times between alternating-color and mono-color sentences. Taken together, these findings suggest that skilled readers of unspaced writing systems learn to develop some nonvisual cues to help delimitate word boundaries during reading (e.g., see Kasisopa, Reilly, Luksaneeyanawin, \& Burnham, 2013, for discussion). Thus, we do not expect (large) differences in reading-aloud times between multicolored and mono-colored texts for standard, easy-to-read texts in Chinese (Experiment 1). Critically, the scenario may be different when adult readers read technical, difficult texts that contain a number of unfamiliar words (Experiment 2) or in an immature word recognition system (Experiment 3). In this latter scenario, the potential benefit from the visual cues that delineate word boundaries may override the cost due to lack of visual familiarity (see Blythe et al., 2012; Shen et al., 2012; Zang et al., 2013, for a similar reasoning with respect to inserting interword spaces). Clearly, if color information does benefit reading aloud a text in Chinese, this would have practical implications for reading instruction and vocabulary acquisition methods in Chinese and presumably other unspaced scripts.

\section{Experiment 1 (adult skilled readers with standard texts)}

\section{Method}

\section{Participants}

Twenty-four students ( 18 females, $M_{\text {age }}=25.7$ years, range: 24-28 years) from Zhejiang University (China) participated voluntarily in the experiment. They were native Mandarin Chinese speakers with normal (or corrected-to-normal) vision, and none of them was color-blind. Informed consent was obtained from all participants.

\section{Materials}

We selected two text passages from the Baidu Encyclopedia. Text A was about the evolution of wolves, and Text B was about the historical review of galaxies. In Text A, there were 384 characters (or 214 words) and 37 punctuation marks; in Text B, there were 384 characters (or 212 words) and 31 punctuation marks. Fifteen university students who did not participate in the readingaloud experiment were asked to evaluate the difficulty of the two texts separately on a 1 to 7 Likert scale $(1=$ very easy, $7=$ very difficult). The data showed similar scores for Text A (mean $=2.0$, $S D=0.7)$ and Text B (mean $=2.2, S D=0.7), t(14)=-1.146, p=$ .271. As there may be some disagreement on word segmentation among Chinese readers, the same raters who evaluated the degree of text difficulty were also asked to rate their agreement on the text segmentation by color on a 1 to 7 Likert scale $(1=$ strongly disagree, 7 = strongly agree). The mean score was 6.9 
$(S D=0.3)$. To color the texts, we chose the same four equiluminant colors (approx. $72.27 \mathrm{~cd} / \mathrm{m}^{2}$ ) that were used in the Pinna et al. (2010) experiment (red [CIE chromaticity coordinates $x, y=0.55,0.37$; RGB 171, 41, 51], green [0.34, 0.51; 78, $167,55]$, brown $[0.49,0.40 ; 178,112,49]$, and blue $[0.17,0.19$; $53,85,142])$. The texts were presented in Song 18-pt. font on a computer screen with a black background. For the mono-colored texts, the characters were presented in red, green, brown, or blue (e.g., $25 \%$ of the participants would receive the mono-color text in red, $25 \%$ in green, $25 \%$ in brown, and $25 \%$ in blue); for the multicolored texts, the color of the words alternated between red, green, brown, and blue (e.g., as in the sentence 在一片广阔的热带 雨林中,住着一只“森林大王”老虎和一只“奔跑之王”猎豹). The two texts are presented in Appendix A. For half of the participants, Text A was presented in multicolored format, and Text B was presented in mono-colored format, whereas for the other half, Text A was presented in mono-colored format, and Text B was presented in multicolored format. The order of presentation of Texts A and B was counterbalanced across participants. Participants were randomly assigned to each of the four counterbalancing conditions.

\section{Design}

The independent variable was color information (alternatingcolor words vs. mono-color words). The main dependent variable was the number of words per minute, but we also collected a reading comprehension score.

\section{Procedure}

The experiment took place individually in a silent room. A computer equipped with DMDX software (Forster \& Forster, 2003) was used to present the stimuli and record the participants' responses. Participants were instructed to read aloud two texts (either in mono-color or multicolor format) while trying to comprehend them. We computed the total reading time in seconds, and this was transformed into words per minute (i.e., reading speed). Each text was followed by two yes/no comprehension questions on the texts. Participants answered these questions orally.

\section{Results and discussion}

The number of words per minute (wpm) and the reading comprehension scores per condition are displayed in Table 1 . Comprehension scores were at ceiling level: $95.8 \%$ and $93.8 \%$ for the multicolor and mono-color texts, respectively. We conducted a paired $t$ test on the participants' reading speed (in wpm) as a function of color format: mono-color versus multicolor. The statistical analyses were conducted using JASP software (JASP Team, 2016).
Results failed to show any differences in reading speed between multicolor and mono-color texts, $t(23)=-.231, p=$ .82 (137.4 vs. 137.9 wpm, respectively). In fact, there was moderate evidence for invariance, as this corresponds to a Bayes factor of $\mathrm{BF}_{01}=4.629$ (i.e., the present data is 4.6 times more likely under the null model than the alternative model, using the standard prior distribution for the alternative model $\sim$ Cauchy $r=0.707$ ).

The present null effect is consistent with previous research in Chinese (e.g., Bai et al., 2008; Zang et al., 2013) and other unspaced scripts (Japanese Kanji: Sainio et al., 2007; Thai: Perea et al., 2015). Before accepting the conclusion that alternating-color words do not facilitate reading aloud text in Chinese with adult skilled readers, it is important to consider an alternative explanation. Color information may be more effective at signaling word boundaries when the text contains technical, infrequent words - in the same way that inserting spaces between words in Chinese is particularly effective when learning new words (Blythe et al., 2012). The texts employed in the current experiment were easy to read: the level of difficulty was rated as 2.0-2.2 out of $7(1=$ very easy, $7=$ very difficult $)$. A stronger test of the role of color information during reading aloud in Chinese would require adult skilled readers to read more difficult texts containing technical, unfamiliar words. This was the goal of Experiment 2. The experimental procedure was parallel to that in Experiment 1, except that we selected two texts extracted from academic papers: one on medical principles of phlegm stagnation and the other on the immune responses of invertebrates. The difficulty level of these two texts was rated around 5.8-5.9 out of 7. As we may be dealing with a small-sized effect, sample size was increased to 40 participants.

\section{Experiment 2 (adult skilled readers with difficult texts)}

\section{Method}

\section{Participants}

Forty college students ( 27 females. $M_{\mathrm{age}}=21.9$ years, range: 19-29 years) from Zhejiang University (China) took part in the experiment. They were native Mandarin Chinese speakers with normal (or corrected-to-normal) vision, and none of them was color-blind. Informed consent was obtained from all participants.

\section{Materials}

Two texts were extracted from two published academic papers. Text A was about the medical principles of phlegm stagnation, and Text $\mathrm{B}$ was about the immune responses of 
Table 1 Reading speed (number of words per minute; standard errors between brackets) and comprehension scores (in percentages; standard errors between brackets) in each of the conditions of Experiments 1-3

\begin{tabular}{llll}
\hline & & Words per minute & $\begin{array}{c}\text { Compreh } \\
\text { ension scores }\end{array}$ \\
\hline Adults (standard) & & $95.8(2.8)$ \\
(Exp. 1 & Multicolored & $137.4(4.1)$ & $93.7(3.4)$ \\
Adults (difficult) & Mono-colored & $137.9(3.1)$ & $85.6(2.5)$ \\
(Exp. 2) & Multicolored & $110.2(2.4)$ & $83.1(2.6)$ \\
Children & Mono-colored & $104.5(2.2)$ & $97.9(2.1)$ \\
(Exp. 3) & Multicolored & $81.5(2.1)$ & $95.8(2.9)$ \\
\hline
\end{tabular}

invertebrates. These texts are presented in Appendix B. To evaluate the difficulty of each text, we recruited the same 15 raters as in Experiment 1. The average level of difficulty of two texts on a 1 to 7 Likert scale was very similar: 5.9 for Text $\mathrm{A}(S D=0.6)$ and 5.8 for Text B $(S D=0.7), t(14)=0.292, p=$ .774 note that the texts in Experiment 2 (mean $=5.8, S D=$ $0.5)$ were more difficult than those in Experiment 1 (mean = $2.1, S D=0.6), t(14)=19.843, p<.001$. These 15 raters also agreed on how the two texts were segmented into words (mean $=6.8, S D=0.4)$. In Text A, there were 394 characters (or 205 words) and 23 punctuation marks; in Text B, there were 394 characters (or 205 words) and 26 punctuation marks. The arrangement of the two texts was the same as in Experiment 1.

\section{Design and procedure}

The design and procedure were the same as in Experiment 1 except that we included four (instead of two) comprehension questions.

\section{Results and discussion}

The reading speed (in words per minute) and the comprehension scores (in percentage) are presented in Table 1. Comprehension scores were $85.6 \%$ and $83.1 \%$ for the multicolor and mono-color texts, respectively (i.e., these scores were quite high despite the difficulty of the texts). As in Experiment 1, we conducted a paired $t$ test on the participants' reading times as a function of color: mono-color versus multicolor.

Results showed faster reading times for the multicolor than for the mono-color texts, $t(39)=3.228, p=.003$ (110.2 vs. $104.5 \mathrm{wpm}$, respectively). This corresponded to a Bayes factor of $\mathrm{BF}_{10}=13.43$ - this index represents $p\left(\right.$ data $\left.\mid \mathrm{H}_{1}\right) / p\left(\right.$ data $\left.\mid \mathrm{H}_{0}\right)$. Thus, given the present data, the alternate hypothesis is 13.43 times more likely than the null hypothesis, using the standard prior distribution for the alternative model $\sim$ Cauchy $r=0.707$. This can be considered as strong support for the alternate hypothesis (see Jeffreys, 1961, for some guidelines on how to interpret Bayes factors).

In sum, color information may facilitate reading aloud in adult Chinese readers when the texts are difficult to readnote that, unsurprisingly, reading speed was lower in the current experiment than in Experiment 1 (107.3 vs. 137.7 wpm, respectively). The question now is whether developing readers (Grade 2 children) also benefit from alternating-color text when reading aloud in Chinese.

\section{Experiment 3 (developing readers)}

\section{Method}

\section{Participants}

Twenty-four second-grade children (13 females, $M_{\text {age }}=7.5$ years, age range: 7-9 years) from a primary school in Taizhou (Zhejiang province, China) took part voluntarily in the experiment. All of them were native speakers of Mandarin Chinese and had normal (or corrected-to-normal) vision. None of them was color-blind or had been diagnosed with learning (or reading) problems. Parental informed consent was obtained for all participants.

\section{Materials}

We selected two text passages that were adapted from primary students' compositions from the Baidu Library. Text A was a story about a tiger, a leopard, and a lion; Text B was a story about shoes and socks. In Text A, there were 377 characters (or 219 words) and 57 punctuation marks; in Text B, there were 377 characters (or 220 words) and 55 punctuation marks. The two texts are presented in Appendix C. In an initial step, two second-grade students who did not participate in the experiment assessed the familiarity of the words. All the words that were not highly familiar were replaced with more familiar words. In a second step, three schoolteachers evaluated the difficulty of the texts and agreed that (1) the two texts were 
appropriate in difficulty for second-grade children, and (2) the two texts were equally reading friendly. In a third step, 14 Grade 2 primary school students who did not take part in the reading aloud experiment assessed the difficulty of the two texts on a 1 to 7 Likert scale ( $1=$ very difficult, $7=$ very easy). Results showed similar scores for Text A (mean $=5.9$, $S D=1.1)$ and Text B (mean $=5.8, S D=0.9), t(13)=0.458, p$ $=0.655$. These individuals also rated their agreement on the text segmentation by color on a 1 to 7 Likert scale ( $1=$ strongly disagree, 7 = strongly agree), and the mean score was 6.9 $(S D=0.4)$. The arrangement of the two texts was the same as in Experiment 1. After reading each text, participants had to answer two comprehension questions.

\section{Design and procedure}

Design and procedure were the same as in Experiment 1.

\section{Results and discussion}

The reading speed (in words per minute) and the comprehension scores (in percentage) are presented in Table 1. Comprehension scores were at ceiling level: $97.9 \%$ and $95.8 \%$ for the multicolor and mono-color texts, respectively. The statistical analyses were analogous to those in Experiments 1 and 2.

Results showed faster reading times for the multicolor than for the mono-color texts, $t(23)=3.55, p=.002(81.53 \mathrm{vs}$. $77.19 \mathrm{wpm}$, respectively). This corresponded to a Bayes factor of $\mathrm{BF}_{10}=22.66$, thus reflecting strong evidence toward the alternate hypothesis (Jeffreys, 1961).

Therefore, this experiment supports the view that, with developing readers, color information provides an effective visual cue to delineate words in Chinese.

\section{General discussion}

In the current experiments, we asked whether color information regarding word boundaries facilitates reading aloud a text in an unspaced script (Chinese). Results showed that color information did help text reading aloud not only for developing readers (Experiment 3 ) but also for adult skilled readers when the texts contained technical, unfamiliar words (Experiment 2). Taken together, these results generalize the findings reported in previous studies (Bai et al., 2013; Blythe et al., 2012) in which inserting interword spaces (i.e., another visual cue) facilitated silent reading in Chinese - in the current experiments, the effect was obtained when reading aloud a text. Importantly, this facilitative effect was obtained using a visual cue (i.e., color information) that does not alter the spatial distribution of the text, thus providing a less intrusive visual cue than inserting interword spaces (see Häikiö, Bertram, \& Hyönä, 2016, for a similar point).

The findings of Experiments 2 and 3 are consistent with the claim that color enhances perceptual grouping during reading (see Häikiö et al., 2015; Perea et al., 2015; Pinna \& Deiana, 2014). Color information can serve as a visual cue to delimit word boundaries, and this facilitates the process of word identification when reading aloud in Chinese. These results may have implications for the reading instruction methods employed in unspaced writing systems (see also Bai et al., 2013; Shen et al., 2012, for discussion). At the early stages of learning to read - or when encountering texts with unfamiliar words - color information may provide an extra visual cue to help to segment the words, eliminating the readers' burden to group the characters to form words. A fair question is to what extent the current findings can be generalized to a silentreading scenario. Previous research has shown that colors are a powerful visual cue to segment words during silent reading in spaced orthographies (e.g., see Perea et al., 2015), which suggests that color information may also have a facilitative effect during silent reading in Chinese. Therefore, while we acknowledge that more data should be gathered, the present findings can be taken to suggest that publishing companies could, in the future, use color information for texts with unfamiliar words and in beginning texts for children (or for learners of Chinese [or other unspaced writing systems] as an L2).

Future research should examine the effect of multicolored text on poor readers compared to typically developing readers during silent reading in Chinese. For letter spacing in the Roman script, the effect of interletter spacing distance (usually interpreted as crowding effects) is larger in poor readers than in typical readers (e.g., see Moll \& Jones, 2013; Perea, Panadero, Moret-Tatay, \& Gómez, 2012; Spinelli, De Luca, Judica, \& Zoccolotti, 2002; Zorzi et al., 2012). Similarly, multicolored text might have differential effects on poor readers compared to good readers. Furthermore, in an applied scenario, it may be desirable to examine both reading speed and comprehension by using texts of various difficulty levelsthese texts would require answering both surface and deep comprehension questions (see Perea et al., 2012, for discussion). We acknowledge that when readers are highly proficient in the reading process - or when the text is easy to read, the effect of color information as a visual cue may diminish. Indeed, as shown in Experiment 1, skilled adult readers of Chinese seem to be capable of effectively segmenting and processing text in the absence of explicit visual cues corresponding to word boundaries; for instance, several adult readers indicated after the experiments that color information was distracting to them.

In sum, the present experiments demonstrated that color information is a powerful visual cue to segment words of an unspaced writing system (Chinese) not only in developing readers but also in adult skilled readers - at least for texts 
containing technical, difficult words. Despite the fact that participants had not been trained to read multicolored text, their reading speed was higher than with mono-colored text. Importantly, alternating color across words keeps exactly the same the spatial distribution of the text as the standard monocolor text in unspaced scripts, thus providing a closer scenario to normal reading than inserting spaces between words-we acknowledge that further research should compare the effectiveness of these two visual cues: insertion of interword spaces and color alternation. The present findings open a window of opportunities for further research. Two research lines seem particularly promising: (a) to examine the developmental trajectory of the effect of color information in Chinese across the different grades of elementary school (or across learning levels, in the case of adult learners of Chinese as L2) - note that a standardized set of texts varying in difficulty would allow a more in-depth evaluation of both reading speed and comprehension; and (b) to register the participants' eye movements when reading multicolored versus mono-colored text in Chinese (or any other unspaced writing system), as this may help determine in detail the time course of the effect of color information during word identification and eye-movement guidance.

Author note The research reported in this article has been partially supported by Grant PSI2014-53444-P from the Spanish Ministry of Economy and Competitiveness. We thank Raymond Bertram, Tuomo Häikiö, and Simon Liversedge for their helpful comments on an earlier version of this article.

\section{Appendix A}

\section{Texts used in Experiment 1}

Text A

百万年前,地球上食物链里有三个顶级杀手,按照威力的大小排 列, 分别是泰坦鸟, 剑齿虎和狼。而如今我们只能看到狼的存在, 为 什么体型巨大, 奔跑迅速以及攻击迅猛的泰坦鸟和剑齿虎却灭绝了 呢? 这两类动物都比狼的体型大,威力猛,但是都缺乏社会体系, 往往 是单独居住或者狩猎。这种独居的最大弊端, 就是无法有效地在 外出捕食时保护幼小, 导致后代的存活率大大降低; 其次, 尽管具备 强大的捕猎能力, 他们消化和进食的速度相对较慢, 时常不能守住 自己的猎物。狼却是团队作战, 可以更加有效地保护后代不受其 他捕食者的侵扰, 而且狼的行动迅速, 善于攻击对手的弱点, 那就是 咬断猎物的大腿根部, 使其㿈疾。之后, 狼群可以在二十分钟以内 吃光一头鹿, 将其变成一堆白骨, 丝毫不给其他动物伺机掠夺自己 财富的机会。因此随着时间的推移, 在漫长的进化过程中,其他顶 级杀手都消亡了, 可狼却因为群体生活、团体捕猎而生存下 来。狼曾经是食物链中最高的霸主。可是一百万年后, 这个地位 被更加善于群体合作的人类所取代。

Questions:

1. 狼的后代存活率高于泰坦鸟和剑齿虎。

2. 狼的消化和进食速度慢。
Baidu Encyclopedia. Text A for adult readers. Retrieved from http://baike.baidu.com/link?url=-TsaMfAeWh2b7gIco50 dgwvtzIwA2PPIwmTEcYYiPC73ZI-wSBAE09GO42ij24VVUEK5LNuCi9EgfCIzSOGa

Translation

Two million years ago, there were three top killers in the food chain on the earth. They were the titan bird, the sabertoothed tiger, and the wolf, with the titan bird the most powerful and the wolf the least powerful among the three. But now we can only see the existence of the wolf. Why did the titan birds and the saber-toothed tigers that were gigantic, ran quickly, and attacked rapidly die out? These two kinds of animals were larger in size and more powerful than the wolf, but they lacked a social system, often living and hunting alone. The biggest disadvantage of living alone was that they were unable to protect their young effectively when they went out hunting, leading to the sharp decrease of the offspring's survival. Second, although the titan bird and the saber-toothed tiger were powerful in hunting, they were relatively slow in digesting and eating, often failing to keep their own prey. On the contrary, the wolves operate as a team, thus they can protect the offspring from other predators more effectively. Moreover, the wolves are quick on the trigger and good at attacking the preys' weakness, which is to bite their thighs and make them paralyzed. Then, the wolves can eat up a deer within 20 minutes, turning it into a pile of bones and leaving no chance for other animals to plunder their wealth. So as time goes on, in the long process of evolution, the other two top killers were extinct, but the wolves survive because they live and hunt in groups. The wolves stood at the top of the food chain, but 1 million years later, humans who were more capable of cooperation occupied that position.

Questions:

1. The wolves have a higher offspring survival rate than that of the titan birds and the saber-toothed tigers.

2 . The wolves are slow in digesting and eating.

Text B

朗的夜空,当你抬头仰望天空的时候,能看见一条淡淡的、纱巾 似的光带跨越整个天空,好像天空中的一条大河, 那就是银河。银 河在夏季成南北方向,冬季成东西方向。过去由于科学还不发 达, 古人不知道银河是什么, 把银河想像成天上的河流。我国著名 的神话故事牛郎织女鹊桥相会就是铺设在这条天河之上,牛郎星是 天鹰座中最亮的星,在银河的东岸;织女星是天琴座中最亮的星,在 银河的西岸。西方人把银河想像成天上的神后喂养婴儿时流淌出 来的乳汁, 因此叫它为牛奶路。美丽的神话故事不能代替令人满 意的科学解释。银河究竟是什么呢?十七世纪初期,伟大的意大利 科学家伽利略发明天文望远镜以后, 发现银河是由上亿颗恒星聚集 在一起而形成的。实际上银河只是银河系的一部分, 是银河系的 主体投影在天球上的亮带,是我们置身其中而侧视银河系时所看到 的布满恒星的圆面。由于恒星发出的光离我们很遥远,数量繁 多,而且与星际尘埃气体混合在一起,人的肉眼分辨不清,因此看起 来就像一条烟雾笼罩着的光带。 
Questions:

1. 我们所看到的银河就是银河系的全部。

2. 伽里略发明了天文望远镜。

Baidu Encyclopedia. Text B for adult readers. Retrieved from http://baike.baidu.com/link?url=zD4ftBvehlS0g7Ag5qcftwaxSYD3hyzM5hSX-nxxkhle7QY19fI9fy_ pneNN5gri_OY8rpZ6oc6BrFKFYF1Lvue3DTIBA6JI8z67hT4I7

Translation

When you look at the sky on a clear night, you can see a light gauze-like band across the sky, looking like a great river in the sky. That is the galaxy. The galaxy is in north-south direction in the summer and east-west direction in the winter. In the past, with the underdevelopment of science, the ancients had no idea about what the galaxy was, so they imagined it as a river in the sky. The famous fairy tale in China that the cowherd (Altair) and the weaving maid (Vega) meet once a year when magpies fly together to form a bridge over the galaxy stems from this river. Altair, which is on the east side of the galaxy, is the brightest star in Aquila; Vega, which is on the west side of the galaxy, is the brightest star in Lyra. Westerners imagine the galaxy as the milk from Hera when she was feeding an infant. So they call it the milky way. The beautiful fairy tale is no substitute for a satisfactory scientific explanation. What is the galaxy? In the early 17 th century, the great Italian scientist Galileo invented the telescope and found that the galaxy is made up of hundreds of millions of stars. Actually, the milky way is just a part of the galaxy. It is the light band formed by the projection of the main body of the galaxy on the celestial sphere, and it is the round surface full of stars that people see from the side when they are placed in. The numerous stars are very far from us and are mixed with the interstellar dust and gas, so it is difficult for people to tell them apart with their naked eyes, making them look like a smogcovered light band.

Questions:

1. The galaxy that we see is the whole part of the galaxy.

2. It is Galileo who invented the telescope.

\section{Appendix B}

Texts used in Experiment 2

Text A

瘀在中医准确地说是痰浊和血瘀。痰浊是由人体津液凝聚变 化而成。血瘀是指全身血液运行不畅, 局部血液停滞以及体内存 在离经之血。中医有痰瘀同源之说, 并认为动脉粥样硬化是痰瘀 同病的症状, 由痰致瘀的关键是“气”的转枢作用; 而西医则发现总 胆固醇、甘油三酯和氧化型低密度脂蛋白升高是血瘀和痰浊的主 要特征和生物化学物质基础。细胞的损伤是由痰致疼的主要病理 特征, 而脂质代谢紊乱及引起脂质代谢紊乱的内外因素是其病因所
在。氧化型低密度脂蛋白的氧化修饰产物可以引起与细胞凋 亡、平滑肌细胞增殖密切相关的细胞信号传递分子活性的显著升 高, 从而引起动脉弹样硬化的发生, 可以认为是由痰致㾉的重要途 径之一。具有健脾理气功效的沥水调脂胶囊可以减弱或抑制氧化 型低密度脂蛋白引起的内皮细胞、平滑肌细胞胞质游离钻离子浓 度升高及平滑肌细胞胞膜蛋白酶活性升高, 表明健脾理气在抗氧化 应激调节细胞的早期信号传递通路方面具有重要功能,为“气可能 和体内氧化作用有某种关联”提供了初步的证据。

Questions:

1. 中医中认为痰瘀是痰浊和血瘀,两者毫不相干, 有不同的病理 症状。

2. 中医上认为痰瘀与气有关, 西医上认为痰瘀和氧化型低密度 脂蛋白的氧化修饰产物相关。

3. 中医认为痰浊可以导致血瘀,动脉湅样硬化就是其中一个症 状表现。

4. 沥水调脂胶囊可以增加氧化型低密度脂蛋白引起的氧化修 饰产物。

From Chen, Song, Niu, Jin, and Yu-Mei (2004).

Translation

Accurately speaking, phlegm stagnation means phlegm and blood stasis. Phlegm originates from condensed human body fluid, while blood stasis is comprehended as poor general blood circulation, which stems from the stagnant movement of local blood and the abnormal flow of blood in the human body. In traditional Chinese medicine, it is said that phlegm and blood stasis are homologues, which cause the same symptom-atherosclerosis. It is also believed that the hinge of qi plays a vital role in the switch from phlegm to blood stasis. Western medicine, however, found phlegm stagnation featured by an increase of total cholesterol, triglyceride, and oxidized low-density lipoprotein, which are also the biological and chemical substances base for phlegm and blood stasis. The main pathological feature of the switch from phlegm to blood stasis is the damage to cells, and its pathogenesis lies in lipid metabolism disorders and the internal and external factors causing them. Oxidized modification products of the oxidized low-density lipoprotein can give rise to a significant increase of the activity of the molecules that carry chemical signals between cells, which is closely related to the apoptosis and the smooth muscle proliferation, leading to the atherosclerosis. This is believed to be one of the important ways phlegm is switched to blood stasis. The Lishui Tiaozhi capsule, which regulates qi and strengthens spleen, is able to attenuate or suppress both the increase of calcium concentration in endothelial cells and smooth muscle cells, and the increase of cell membrane protease's activation in smooth muscle cells. It indicates that regulating qi and strengthening spleen plays a crucial role in the early signal transduction pathway in the antioxidant stress-regulating cells. It also provides preliminary evidence for the claim that qi may correlate with the oxidation in vivo. 
Questions:

1. In traditional Chinese medicine, the phlegm has nothing to do with the blood stasis and they have different symptoms.

2. Traditional Chinese medicine holds that the phlegm stagnation is concerned with qi, while Western medicine believes that it correlates with the oxidized modification products of the oxidized low density lipoprotein.

3. Traditional Chinese medicine believes that phlegm and blood stasis are homologous, and they share the symptom atherosclerosis.

4. Lishui Tiaozhi capsule is able to increase oxidized modification products caused by the oxidized low density lipoprotein.

Text B

脊椎动物遭受微生物感染后可引起多种细胞和体液免疫反应 的激活, 从微生物侵袭到最终清除病原一般要经过下列几个步 骤:首先是这些无脊椎动物对感染的非已识别;随后,引发了激活丝 氨酸蛋白酶和解除丝氨酸蛋白酶抑制剂的细胞外级联反应, 从而将 收到感染的信号放大为更强的危险信号或解除错误警报; 然后, 通 过信号转导途径引起目的转录基因的激活; 最后, 激活了效应物反 应系统,包括吞噬作用、包被作用、激活蛋白酶级联反应和黑化 作用以及诱导抗菌肽的合成等, 从而清除或消灭入侵物。研究证 明, 这种非已识别是因为存在某些特异性的、可溶的或与细胞膜 结合的模式识别受体, 可以识别或结合微生物表面保守的、而在 宿主中又不存在的病原相关分子模式。可见, 模式识别受体是通 过识别病原相关分子来启动先天免疫防御。然而, 不同的模式识 别受体可以引起不同的免疫防御反应。比如肽聚糖识别蛋白可以 引起黑化级联反应, 吞噬作用和信号转导; 而革兰氏阴性菌结合蛋 白在对细菌脂多糖反应的先天免疫信号转导中起作用。

Questions:

1. 无脊椎动物拥有先天免疫防御系统。

2. 无脊椎动物的免疫反应的一步关键步骤是对非己的识别。

3. 非已识别的关键是无脊椎动物的模式识别受体, 不同的模式 识别受体可引起相同的免疫防御反应。

4. 模式识别受体不能与细胞膜相结合。

From Wang and Zhao (2004).

Translation

After being infected with microorganisms, invertebrates usually activate various cellular and humoral immune responses. There are several steps as follows to clean the pathogens when the invertebrates suffer the inflection. First, they need to recognize the microorganism as the "nonself." Then, the extracellular cascade reaction that activates serine proteases and relieves the serine protease inhibitor is triggered to amplify the signal of inflection to a stronger danger signal, or to remove the false alarm. This is followed by the activation of the target open gene through the signal transduction pathway. At last, the effector response system will be activated to remove or destroy the invaders, including the phagocytosis, the encapsidation, the activation of protease's cascade reaction and melanization, the synthesis of antimicrobial peptide, and so on. Studies have shown that the recognition of the nonself is attributed to the existence of some pattern recognition receptors that are either specific and soluble or able to combine with the cell membrane. They can recognize or combine with the conservative pathogen-associated molecular patterns at the surface of the microorganisms, which does not exist in the host cells. It can be seen that the pattern recognition receptors activate innate immune responses through the recognition of pathogen-associated molecules. But the immune responses vary among different pattern recognition receptors. For example, the peptidoglycan recognition protein could lead to a melanization cascaded reaction, phagocytosis, and signal transduction, while the gram-negative bacteria binding protein plays a part in innate immune signal transduction in bacterial lipopolysaccharide reaction.

Questions:

1. The invertebrates have innate immune defense system.

2. An important step of the immune responses in invertebrates is the recognition of the nonself.

3. The key to recognizing the nonself is the existence of the pattern recognition receptors and different pattern recognition receptors will lead to the same immune defense reaction.

4. The pattern recognition receptors cannot combine with the cell membrane.

\section{Appendix C}

Texts used in Experiment 3

Text A

一片广阔的热带雨林中,住着一只“森林大王”老虎和一只“奔 跑之王”猎豹。有一天清晨, 太阳高照,鲜花开放。一条弯弯的小 路上走来那只“森林大王”老虎,他十分饥饿。另一旁的草丛里,有 一只刚出生的小水牛在睡觉,浑身粉嫩粉嫩的,散发着醉人的肉 香。老虎眼睛一亮, 渐渐靠近了小水牛。这时那只“奔跑之王”猎 豹刚磨完爪子,也出来找吃的。他也发现了小水牛, 径直向绿油油 的草从跑过来。老虎和猎豹碰面了。猎豹悄悄地问老虎: “老虎大 哥, 我们一起发现了小水牛, 不如我们来比个高低, 谁输了谁走, 谁赢 了小水牛就归他。”老虎点点头同意了。他们走到一片空地上, 还 请来了狮子当裁判。狮子一本正经地说: “在森林里你们都很有本 事! 你们看, 对面有一座高山, 谁先爬上山顶, 谁就获胜。”狮子刚说 完, 老虎和猎豹都拼命地朝山上奔去。狮子眨眨眼睛,得意地笑 了:“这两个愚蚌的家伙, 小水牛现在是我的美餐了!’狮子走到草丛 跟前, 叮起小水牛消失在茂密的大森林里。老虎和猎豹仍旧不知 道上了狮子的当,他们还在拼命地继续向山顶奔跑着。

Questions:

1. 狮子,老虎和猎豹都想吃小水牛。

2. 老虎最后赢得了小水牛。

Translation

In a vast tropical rain forest, there lived a "king of the forest," the tiger, and a "king of running," the leopard. On a morning, the sun was shining and the flowers blossomed. The king of the forest, the tiger, walked on a curved path, and he was very hungry. On the other side of the grass, a small newborn buffalo was sleeping. It was pink and delicate, exuding 
the intoxicating fragrance of meat. The tiger's eyes lighted up, and it approached the buffalo gradually. At the same time, the king of running, the leopard, just polished its claws and came out to look for food. He also found the small buffalo and ran straight to the green grass. The tiger and the leopard met. The leopard asked the tiger quietly, "Tiger, elder brother, both of us found the small buffalo. How about a contest? The winner gets the buffalo and the loser leaves." The tiger nodded and agreed. They went to a clearing and also invited the lion to be the referee. The lion said solemnly, "You two are both powerful in the forest! Look, there is a mountain, the first one who arrive at the top of the mountain will win." Just the moment the lion finished talking, the tiger and leopard immediately ran desperately toward the mountain. The lion blinked its eyes and smiled, satisfied: "What two stupid guys! Now the small buffalo is my dish!" The lion came to the grass, held the small buffalo in its mouth, and disappeared into the dense forest. Having not realized that they were cheated by the lion, the tiger and the leopard were still running desperately toward the top of the mountain.

Questions:

1. The lion, the tiger, and the leopard all wanted to get the buffalo.

2. At last, the tiger won the buffalo.

Text B

前, 有一双会说话的袜子和一双鞋子是好朋友。每当主人穿这 双袜子一定会穿上那双鞋子。一天, 袜子和鞋子吵得不可开 交。鞋子说:“你怎么这么臭,我头都臭晕了!?”袜子说:“是你身上发 出的臭味,你看你还是橡胶底。”鞋子又说:“你没良心,我每天任劳 任怨地保护着你。如果不是我,你身上不知有多脏呢! ”袜子满不在 乎。第二天, 鞋子罢工了。主人只穿着袜子上路, 薄薄的袜子踏在 地上, 脚冻得通红。不一会儿, 袜子磨出了一个小窟䏺。袜子病 了,主人让它休息。该鞋子工作了,光光的脚 Y伸进鞋子里,冷冰冰 的, 非常不舒服。别人瞧见了, 背地里还对主人指指点点, 偷偷地发 笑呢! 主人很没面子, 回到家很不高兴。脚知道自己没有把袜子和 鞋子的工作做好, 丢了主人的脸。于是找来袜子和鞋子, 语重心长 地对他们说: “你们都不要说别人臭了, 其实是我的错, 是我出了汗才 惹得你们发出臭味, 以后我会勤洗澡。”袜子和鞋子听见脚大哥在 批评自己,都不好意思地低下了头。从此袜子和鞋又变成形影不 离的好朋友。它们陪伴着主人快乐地度过每一天。

Questions:

1. 袜子和鞋子从来不吵架。

2 . 是因为脚出汗才惹得袜子和鞋子发臭。

Translation

Once upon a time, a pair of socks and a pair of shoes who can speak were good friends. When the owner wore this pair of socks, he would put on that pair of shoes. One day, socks and shoes quarreled seriously. The shoes said, "Look how smelly you are! It makes me light-headed!" The socks replied, "It's you who emit the smell. You see, you are rubber-soled shoes." Then the shoes said, "How unconscionable you are! I work hard every day to protect you. Without me, you've no idea how dirty you will be!" The socks didn't give a rap. The next day, the shoes went on strike and the owner had to wear only socks to walk on the road. With just such thin socks to stand on the floor, the feet turned red with cold. After a while, the socks were worn into holes. Then the socks were ill, so the owner let them rest. Then the shoes were on duty. The feet were very uncomfortable when they were bare in the cold shoes. Others who noticed this kept talking about the owner behind his back, and laughed at him secretly! The owner lost face and was very unhappy when he went back home. The feet thought it was their fault that made their owner lose face as they didn't work on socks and shoes. So the feet got socks and shoes together and said sincerely and sternly to them, "Don't blame each other for the stink. Actually, it's my fault. I make the stink out of the sweat. I will take shower regularly in the future." Hearing that the feet elder brother was criticizing himself, socks and shoes felt embarrassed and bowed their heads. From then on, socks and shoes became inseparable friends. They spent every day happily with their owner.

Questions:

1. The socks and the shoes never quarreled with each.

2. It is the sweat from the feet that makes the shoes and socks stink.

Baidu Library. Texts A \& B for developing readers. Retrieved from http://wenku.baidu.com/view/ 929aad0cf78a6529647d536c.html

\section{References}

Bai, X., Liang, F., Blythe, H. I., Zang, C., Yan, G., \& Liversedge, S. P. (2013). Interword spacing effects on the acquisition of new vocabulary for readers of Chinese as a second language. Journal of Research in Reading, 36, S4-S17. doi:10.1111/j.1467-9817.2013. 01554.x

Bai, X., Yan, G., Liversedge, S. P., Zang, C., \& Rayner, K. (2008). Reading spaced and unspaced Chinese text: Evidence from eye movements. Journal of Experimental Psychology: Human Perception and Performance, 34, 1277-1287. doi:10.1037/00961523.34.5.1277

Blythe, H. I., Liang, F., Zang, C., Wang, J., Yan, G., Bai, X., \& Liversedge, S. P. (2012). Inserting spaces into Chinese text helps readers to learn new words: An eye movement study. Journal of Memory and Language, 67, 241-254. doi:10.1016/j.jml.2012.05.004

Chen, B., Song, J. N., Niu, X. H., Jin, H., \& Yu-Mei, L. I. (2004). Effect of jianpi qutan huayu recipe on the expression of $[\mathrm{Ca} 2+] \mathrm{i}$ and protein kinase $\mathrm{c}$ of blood vessel cells induced by oxidized low density lipoprotein. Chinese Journal of Arterial Lerosis, 12, 143-146. Chinese version.

Forster, K. I., \& Forster, J. C. (2003). DMDX: A Windows display program with millisecond accuracy. Behavior Research Methods, Instruments, and Computers, 35, 116-124. doi:10.3758/s13428014-0493-8

Goldfarb, L., \& Treisman, A. (2011). Does a color difference between parts impair the perception of a whole? A similarity between simultanagnosia patients and healthy observers. Psychonomic Bulletin and Review, 18, 877-882. doi:10.3758/s13423-011-0123-8

Häikiö, T., Bertram, R., \& Hyönä, J. (2016). The hyphen as a syllabification cue in reading bisyllabic and multisyllabic words among 
Finnish 1st and 2nd graders. Reading and Writing, 29, 159-182. doi: 10.1007/s11145-015-9584-x

Häikiö, T., Hyönä, J., \& Bertram, R. (2015). The role of syllables in word recognition among beginning Finnish readers: Evidence from eye movements during reading. Journal of Cognitive Psychology, 27, 562-577. doi:10.1080/20445911.2014.982126

JASP Team. (2016). JASP (Version 0.7.5.5) [Computer software]. Retrieved from https://jasp-stats.org/

Jeffreys, H. (1961). Theory of probability (3rd ed.). New York: Oxford University Press.

Kasisopa, B., Reilly, R. G., Luksaneeyanawin, S., \& Burnham, D. (2013). Eye movements while reading an unspaced writing system: The case of Thai. Vision Research, 86, 71-80. doi:10.1016/j.visres.2013.04. 007

Leyland, L.-A., Kirkby, J. A., Juhasz, B. J., Pollatsek, A., \& Liversedge, S. P. (2013). The influence of word shading and word length on eye movements during reading. Quarterly Journal of Experimental Psychology, 66, 471-486. doi:10.1080/17470218.2011.599401

Li, X., Bicknell, K., Liu, P., Wei, W., \& Rayner, K. (2014). Reading is fundamentally similar across disparate writing systems: A systematic characterization of how words and characters influence eye movements in Chinese reading. Journal of Experimental Psychology: General, 143, 895-913. doi:10.1037/a0033580

Liu, P., Li, W., Lin, N., \& Li, X. (2013). Do Chinese readers follow the national standard rules for word segmentation during reading? PLOS ONE, 8, e55440. doi:10.1371/journal.pone.0055440

Livingstone, M., \& Hubel, D. (1988). Segregation of form, color, movement, and depth: Anatomy, physiology, and perception. Science, 240, 740-749. doi:10.1126/science.3283936

Moll, K., \& Jones, M. (2013). Naming fluency in dyslexic and nondyslexic readers: Differential effects of visual crowding in foveal, parafoveal, and peripheral vision. Quarterly Journal of Experimental Psychology, 66, 2085-2091. doi:10.1080/17470218. 2013.840852

Perea, M., \& Acha, J. (2009). Space information is important for reading. Vision Research, 49, 1994-2000. doi:10.1016/j.visres.2009.05.009

Perea, M., Panadero, V., Moret-Tatay, C., \& Gómez, P. (2012). The effects of inter-letter spacing in visual-word recognition: Evidence with young normal readers and developmental dyslexics. Learning and Instruction, 22, 420-430. doi:10.1016/j.learninstruc.2012.04. 001

Perea, M., Tejero, P., \& Winskel, H. (2015). Can colours be used to segment words when reading? Acta Psychologica, 159, 8-13. doi: 10.1016/j.actpsy.2015.05.005

Pinna, B., \& Deiana, K. (2014). New conditions on the role of color in perceptual organization and an extension to how color influences reading. Psihologija, 47, 319-351. doi:10.2298/PSI1403319P

Pinna, B., Uccula, A., \& Tanca, M. (2010). How does the color influence figure and shape formation, grouping, numerousness and reading? The role of chromatic wholeness and fragmentation. Ophthalmic and Physiological Optics, 30, 583-593. doi:10.1111/j.1475-1313. 2010.00743.x

Pollatsek, A., \& Rayner, K. (1982). Eye movement control in reading: The role of word boundaries. Journal of Experimental Psychology: Human Perception and Performance, 8, 817-833. doi:10.1037/ 0096-1523.8.6.817

Rayner, K., Fischer, M. H., \& Pollatsek, A. (1998). Unspaced text interferes with both word identification and eye movement control. Vision Research, 38, 1129-1144. doi:10.1016/s0042-6989(97) 00274-5

Reingold, E. M., Sheridan, H., Meadmore, K. L., Drieghe, D., \& Liversedge, S. P. (2016). Attention and eye-movement control in reading: The selective reading paradigm. Journal of Experimental Psychology: Human Perception and Performance, 4, 2003-2020. doi:10.1037/xhp0000291

Sainio, M., Hyönä, J., Bingushi, K., \& Bertram, R. (2007). The role of interword spacing in reading Japanese: An eye movement study. Vision Research, 47, 2575-2584. doi:10.1016/j.visres.2007.05.017

Shen, D., Liversedge, S. P., Tian, J., Zang, C., Cui, L., Bai, X., ... \& Rayner, K. (2012). Eye movements of second language learners when reading spaced and unspaced Chinese text. Journal of Experimental Psychology: Applied, 18, 192-202. doi:10.1037/ a0027485

Spinelli, D., de Luca, M., Judica, A., \& Zoccolotti, P. (2002). Crowding effects on word identification in developmental dyslexia. Cortex, 8 , 179-200. doi:10.1016/S0010-9452(08)70649-X

State Administration of Quality Supervision, and Standardization Administration of China. (1993). Contemporary Chinese language word segmentation specification for information processing. Beijing: China Standards Press.

Treisman, A., \& Gelade, G. (1980). A feature integration theory of attention. Cognitive Psychology, 12, 97-136. doi:10.1016/00100285(80)90005-5

Wang, J., \& Zhao, X. (2004). Progress in pattern recognition receptors of innate immunity in invertebrates. Progress in Biochemistry \& Biophysics, 31, 112-117. Chinese version.

Winskel, H., Radach, R., \& Luksaneeyanawin, S. (2009). Eye movements when reading spaced and unspaced Thai and English: A comparison of Thai-English bilinguals and English monolinguals. Journal of Memory and Language, 61, 339-351. doi:10.1016/j. jml.2009.07.002

Zang, C., Liang, F., Bai, X., Yan, G., \& Liversedge, S. P. (2013). Interword spacing and landing position effects during Chinese reading in children and adults. Journal of Experimental Psychology: Human Perception and Performance, 39, 720-734. doi:10.1037/ a0030097

Zorzi, M., Barbiero, C., Facoetti, A., Lonciari, I., Carrozzi, M., Montico, M., ... \& Ziegler, J. C. (2012). Extra-large letter spacing improves reading in dyslexia. Proceedings of the National Academy of Sciences, 109, 11455-11459. doi:10.1073/pnas.1205566109 